\title{
Pre-University Education Curriculum Reform and the Generic Learning Skills of Medical School Entrants: Lessons Learned from South Africa
}

\author{
Vanessa Celeste Burch ${ }^{1}$, Cynthia N. T. Sikakana ${ }^{2}$, Geney Dalene Gunston ${ }^{3}$, Sue R. Whittle ${ }^{4}$, \\ Deborah Murdoch-Eaton ${ }^{5}$ \\ 'Department of Medicine, Faculty of Health Sciences, University of Cape Town, '2Department of Integrative Biomedical Sciences, Division of \\ Medical Biochemistry, Faculty of Health Sciences, University of Cape Town, ${ }^{3}$ Department of Human Biology, Faculty of Health Sciences, University \\ of Cape Town, Cape Town, South Africa, " $D$ Department of Molecular and Cellular Biology, Faculty of Biological Sciences, University of Leeds, Leeds, \\ United Kingdom, ${ }^{5}$ Academic Unit of Medical Education, The Medical School, University of Sheffield, Sheffield, United Kingdom
}

\begin{abstract}
Background: Pre-university education curriculum changes may increase the skills and knowledge gap between secondary (high school) and tertiary (university) education that have been identified as having a major impact on the success of students from underresourced educational backgrounds. This study investigated the impact of extensive pre-university curriculum revision on the generic learning skills of entrants to South African medical schools, which admit students directly from high school. Methods: In this prospective study, students entering four medical schools during 2008-2011 were surveyed to determine their practice of and confidence in information handling, managing own learning, technical and numeracy skills, and computer, organizational, and presentation skills in the 12-month preceding entry. The 2008 entrants were the final cohort of the old secondary school curriculum. The mean levels of practice or confidence of entrants to the four medical schools, during 2008-2011, were compared using analysis of variance. The Bonferronis test was used for further pair-wise comparison of cohorts of students either entering in different years or different institutions. Results: While entrants at the four medical schools did not demonstrate a consistent or sustained change in their practice of or confidence in each skill category over the period of study, there were some significant differences between entrants at the respective institutions. Furthermore, entrants to one medical school were consistently less confident of their skills, despite more practice. These findings are best accounted for by the long-standing history of inequitably resourced pre-university education in South Africa. Discussion: These findings highlight the need for close monitoring of the impact of pre-university education changes on the learning skill profiles of university entrants, in order to design effective university programs which enable students from diverse backgrounds to participate and adequately meet curricula demands.
\end{abstract}

Keywords: Curriculum change, generic learning skills, medical students, pre-university education

\section{Background}

Generic learning skills are essential prerequisites for success in higher education and they should be acquired early in educational

\begin{tabular}{|l|l|}
\hline \multicolumn{2}{|c|}{ Access this article online } \\
\hline Quick Response Code: & Website: \\
\hline & www.educationforhealth.net \\
\hline
\end{tabular}

Address for correspondence:

Dr. Geney Dalene Gunston, Department of Human Biology, Faculty of Health Sciences, University of Cape Town, Anzio Road, Observatory, 7925, Cape Town, South Africa.

E-mail: geney.gunston@uct.ac.za life, certainly before reaching university. ${ }^{[1]}$ Some skills, such as critical thinking and the ability to interpret and apply information, are core to the application of knowledge, while others, such as teamwork, collaborative learning, communication, and personal effectiveness, underpin the key aspects of professionalism.

Deficiencies in generic learning skills such as problem-solving, critical thinking, and those promoting self-efficacy, including

This is an open access journal, and articles are distributed under the terms of the Creative Commons Attribution-NonCommercial-ShareAlike 4.0 License, which allows others to remix, tweak, and build upon the work non-commercially, as long as appropriate credit is given and the new creations are licensed under the identical terms.

For reprints contact: reprints@ medknow.com

How to cite this article: Burch VC, Sikakana CN, Gunston GD, Whittle SR, Murdoch-Eaton D. Pre-university education curriculum reform and the generic learning skills of medical school entrants: Lessons learned from South Africa. Educ Health 2018;31:25-31. 
time management, are known to contribute to attrition from higher education. ${ }^{[2-5]}$ Conversely, academic success has been aligned to competence in self-regulated learning, which is clearly underpinned by a range of generic learning skills. Competent and effective self-regulating learners can judge the quality of their own work through critical reflection on progress, and therefore can adjust their approaches to learning in relation to the challenges posed by the situation..$^{[6,7]}$

Furthermore, well-developed generic learning skills are essential for coping with the challenges posed by high-volume, high-intensity undergraduate medical training programs. It is no longer possible to teach medical students all they need to know, and so the doctors of tomorrow need to be equipped with skills to sustain lifelong self-directed learning. In addition, the $21^{\text {st }}$ century clinicians need to be adept at responding to continuously and rapidly changing global health-care needs. ${ }^{[8,9]}$ In order to keep pace with the increasing demand for learning skills, it is essential that health science educators are fully appraised of the generic learning skill profiles of medical school entrants to ensure that medical curricula address learning needs as they are identified..$^{[10]}$

Over the past decade, secondary school curricula have been revised in countries such as the UK (Curriculum 2000), with the specific purpose of improving the generic learning skills of school-leavers, thereby better preparing them for university life. ${ }^{[1]]}$ Monitoring the ongoing impact of these changes is essential if the current medical education strategies are to keep pace with pre-university educational reform. ${ }^{[10,12,13]}$ It is particularly critical to understand the impact on the generic learning skills of university entrants when extensive changes in primary and secondary school curricula are implemented in settings where pre-university education is inequitably resourced.

\section{Context}

In South Africa, the abolition of Apartheid in 1994 ended the racial segregation of all levels of education, which was introduced in 1953 (Bantu Education Act). ${ }^{[14]}$ Extensive curriculum changes have occurred in the South African school system after democracy was established in 1994. In particular, fundamental changes in primary and secondary education were implemented in 2004 [Table 1],,$^{[1,15]}$ and students entering higher education from 2009 onward are the product of a new outcome-based curriculum aimed at empowering learners with a greater repertoire of generic learning skills, rather than just discipline-specific knowledge. The skills identified include critical thinking, problem-solving, information retrieval, the responsible use of science and technology, group work, managing own learning, effective communication, and an understanding of the world as a set of interconnected systems. ${ }^{[15]}$
Table 1: Key principles of the revised national curriculum for primary and secondary education in South Africa

Social justice: Empowerment of previously disadvantaged learners by lack of knowledge and skills

High level of knowledge and skills for all

Clarity: Clearly defined goals and outcomes

Accessibility: Curriculum available in all 11 languages and Braille

Integration: Learning areas are linked and related

Conceptual progression: Curriculum sets out progressively broader and deeper expectations of learners

Articulation: Promotes access from one qualification to another

Portability: Transfer of parts of a qualification to another program within the same qualification

Source: Ministerial Project Committee Republic of South Africa. Revised National Curriculum Statement Grades R-9 Schools. Pretoria: Department of Education; 2002. Available from: http://www.education.gov.za/LinkClick.aspx?fileticket=WJoXaOgvys4\%3D\&tabid=266\&m id=720. [Last accessed on 2018 June 04]

Source: Ministerial Project Committee Republic of South Africa. National Curriculum Statement Grades 10-12 (General) Overview. Pretoria: Department of Education; 2003. Available from: http://www.wced.pgwc.gov.za/documents/education-related/ncs_10-12 overview.pdf. [Last accessed on 2018 June 04]

Despite dramatic increases in education expenditure, radical changes in educational policy, curriculum transformation, and improved access to basic education, gross inequalities in pre-university education in South Africa persist. ${ }^{[16]}$ While the relationship between learner performance and the quality of education that learners receive is complex, factors negatively influencing learners' performance include rapid expansion of the education system producing large numbers of poor quality institutions, ${ }^{[17]}$ limited teachers' subject knowledge despite training, ${ }^{[18,19]}$ inefficient use of classroom teaching time, ${ }^{[20]}$ ineffective school management practices, ${ }^{[2]]}$ and poor access to basic resources such as textbooks. ${ }^{[2]}$ All these challenges are mainly encountered in primary and secondary schools located in low socioeconomic areas. ${ }^{[20]}$

In the face of such educational inequality, it is possible that implementation of a new primary and secondary school curriculum may have exacerbated the potential disparity in the generic learning skill profiles of school-leavers entering university in South Africa. ${ }^{[23,24]}$ Furthermore, this variability may be further accentuated by the changing profile of university entrants as a result of widening access to higher education for students from underrepresented groups. Such potential threats to the early academic success of students pursuing tertiary education need to be identified and addressed to ensure retention and academic progression, particularly of academically-at-risk students, in costly programs such as medicine. This information is essential to determine the need for, and nature of, intervention that may be required at university level.

Given these significant challenges facing higher education in South Africa, and the need to effectively address them, this study was conducted to determine whether the radical changes introduced by the new pre-university education 
curriculum have had a sustained and systematic effect on the generic learning skills of South African medical school entrants.

\section{Methods}

\section{Study participants}

Four universities in South Africa participated in this prospective study investigating the generic learning skill profiles of $1^{\text {st }}$-year students entering medical school between 2008 and 2011. Entrants to South African medical training programs are predominantly school-leavers (coming directly from high school), representing more than $85 \%$ of admissions. ${ }^{[25]}$ As shown in Table 2, the participating universities were representative of the diversity of students entering the country's medical school with respect to ethnicity, geographic location, socioeconomic status and educational background. Indicators that were used as a measure of the resourcing of primary and secondary education were as follows: number of learners per school (smaller schools in rural provinces); learner: teacher ratio (higher ratios in rural provinces); teacher: school ratio (fewer teachers in rural provinces), and the percentage of learners attending privately funded primary and/or secondary schools (small percentage in rural provinces). Table 2 shows that schools $\mathrm{A}$ and $\mathrm{D}$ are located in urban provinces with better primary and secondary education resources and high average household income (USD 19,819 and USD 21,621, respectively). In contrast, schools B and C are located in predominantly rural provinces with less well-resourced primary and secondary education. Medical school C, in particular, is located in a rural province with significantly less educational resources and an average household income (USD 8870) which is less than half of that of the provinces where schools A and D are located.

\section{Study instrument}

The study questionnaire contained 31 individual generic learning skill items aggregated into six skill categories, namely information handling, technical and numeracy skills, computer skills, organizational skills, managing your own learning, and presentation skills. The questionnaire was previously validated with Cronbach's alpha of $0.88 .^{[10]}$ Factor analysis confirmed stability of items within the skill categories and suitability of the questionnaire for use in the South African context. ${ }^{[25]}$

\section{Procedure}

Ethical approval for the study was granted by each individual medical school's relevant research ethics review committee, with three of the four South African schools requiring full anonymization from data collection phase and thus not allowing identification of respondents. Consent by the study participants was taken as completion of the study questionnaire, following an introduction to the purpose of the study, discussion of confidentiality, and an opportunity for asking questions. This all happened at a session within the first 4 weeks of arrival at university.

Students completed a paper version of the questionnaire in which they reported how frequently they had practiced each of the 31 generic learning skills in the 12 months preceding admission to medical school and also their level of confidence in each of these skills. Their reports reflected their experience in the final year of secondary education. Participants rated each skill using an anchored 4-point scale ranging from 1 (never) to 4 (every week) for frequency of practice and 1 (little or no experience) to 4 (more than I need, I often help others) for level of confidence.

\section{Table 2: Key features of four medical schools studied and the provinces in which they are located}

Medical schools studied ${ }^{[1]}$

\begin{tabular}{|c|c|c|c|c|c|c|c|c|c|c|}
\hline $\begin{array}{l}\text { Medical } \\
\text { school }\end{array}$ & Curricular approach & $\begin{array}{l}\text { Language of } \\
\text { instruction }\end{array}$ & $\begin{array}{l}\text { Population } \\
\text { size }\end{array}$ & $\begin{array}{c}\text { Population } \\
\text { density } \\
\text { (people/km²) }\end{array}$ & $\begin{array}{l}\text { Population } \\
\text { in urban } \\
\text { areas (\%) }\end{array}$ & $\begin{array}{c}\text { Average annual } \\
\text { household } \\
\text { income (USD) }{ }^{[6]}\end{array}$ & $\begin{array}{c}\text { Total } \\
\text { number of } \\
\text { learners }\end{array}$ & $\begin{array}{l}\text { Learner: } \\
\text { Teacher } \\
\text { ratio }\end{array}$ & $\begin{array}{l}\text { Learner: } \\
\text { School } \\
\text { ratio }\end{array}$ & $\begin{array}{c}\text { Learners } \\
\text { in private } \\
\text { schools (\%) }\end{array}$ \\
\hline$A$ & $\begin{array}{l}\text { Integrated, system } \\
\text { based }\end{array}$ & $\begin{array}{l}\text { English and } \\
\text { Afrikaans }\end{array}$ & 5.82 & 45 & 88.9 & 19,819 & 962,008 & 28.8 & 620.7 & 2.5 \\
\hline B & $\begin{array}{l}\text { Integrated, system } \\
\text { based }\end{array}$ & $\begin{array}{l}\text { English and } \\
\text { Afrikaans }\end{array}$ & 2.75 million & 21.1 & 68.8 & 10 & 670 & 28.7 & 400.4 & 2.2 \\
\hline C & Problem-based learning & English & 6.56 million & 38.8 & 36.6 & 8870 & $2,079,994$ & 31.3 & 357.1 & 2.0 \\
\hline D & Problem-based learning & English & 12.27 million & 675.1 & 97 & 21,621 & $1,894,027$ & 29.5 & 787.5 & 9.4 \\
\hline \multicolumn{11}{|c|}{$\begin{array}{l}\text { 2. Source: Statistics South Africa } 2003 \text { Census 2001. Investigation into Appropriate Definitions of Urban and Rural Areas of South Africa: A Discussion Document. Pretoria: Statistics South Africa; } \\
\text { p. 8. Available from: http://www.statssa.gov.za/census/census_2001/urban_rural/urbanrural.pdf. [Last accessed on } 2018 \text { June 04] }\end{array}$} \\
\hline \multicolumn{11}{|c|}{$\begin{array}{l}\text { 3. Source: Statistics South Africa 2012(a) and 2012(b). Census 2011: Census in Brief. Pretoria, Statistics South Africa; p. 9, 18. Available from: http://www.statssa.gov.za/census/census_2011/ } \\
\text { census_products/Census_2011_Census_in_brief.pdf. [Last accessed on } 2018 \text { June 04] }\end{array}$} \\
\hline \multicolumn{11}{|c|}{$\begin{array}{l}\text { 4. Source: Statistics South Africa. Census 2011: Provinces at a Glance. Pretoria. Statistics South Africa; p. 43. Available from: http://www.statssa.gov.za/census/census_2011/census_products/ } \\
\text { Provinces\%20at\%20a\%20glance\%2016\%20Nov\%202012\%20corrected.pdf. [Last accessed on } 2018 \text { June 04] }\end{array}$} \\
\hline \multicolumn{11}{|c|}{ 5. Source: Republic of South Africa. Education Statistics in South Africa 2010. Pretoria: Department of Basic Education; 2012. p. 14.} \\
\hline \multicolumn{11}{|c|}{$\begin{array}{l}\text { 6. Average Annual Exchange Rate in 2011: } 1 \text { ZA Rand=0.138596 US Dollar. USF Rex Foreign Exchange Services. Available from: http://www.usforex.com/forex-t } \\
\text { yearly-average-rates. [Last accessed on } 2018 \text { June 04] }\end{array}$} \\
\hline
\end{tabular}

Estimated population size, population density, and average annual household income of provinces in which medical schools are located ${ }^{[2-4]}$

Education for Health • Volume 31 • Issue 1 (January-April 2018)

School facilities in the provinces in which the medical schools are located ${ }^{[5]}$ 04] 
Burch, et al:: Pre-university curriculum reform and generic learning skills

\section{Data analysis}

The data were captured into a database, and statistical analysis was performed utilizing SPSS Statistics for Windows, Version 17.0. Chicago: SPSS Inc. and GRAPHPAD PRISM 4.00 for Windows (Graphpad Software, San Diego, CA, USA). The mean levels of frequency of practice or confidence of entrants to the four medical schools, during 2008-2011, were compared using analysis of variance. Bonferroni's multiple comparison test was used to further compare means for pairs of cohorts of students either entering in different years or entering different institutions.

\section{Results}

The average number of respondents to the generic learning skill questionnaire in each medical school, during 2008-2011, was A (233, range: 205-263); B (147, range: 144-151); C (92, range: 74-108), and D (166, range: 105-214).

\section{Generic learning skills' frequency of practice}

The mean ratings of the frequency of practice for the different generic learning skill categories reported by the $1^{\text {st }}$-year medical students at the four medical schools, during 2008-2011, are presented in Figure 1.

Table 3 presents the mean frequencies of practice for the six categories of generic learning skills studied in each medical

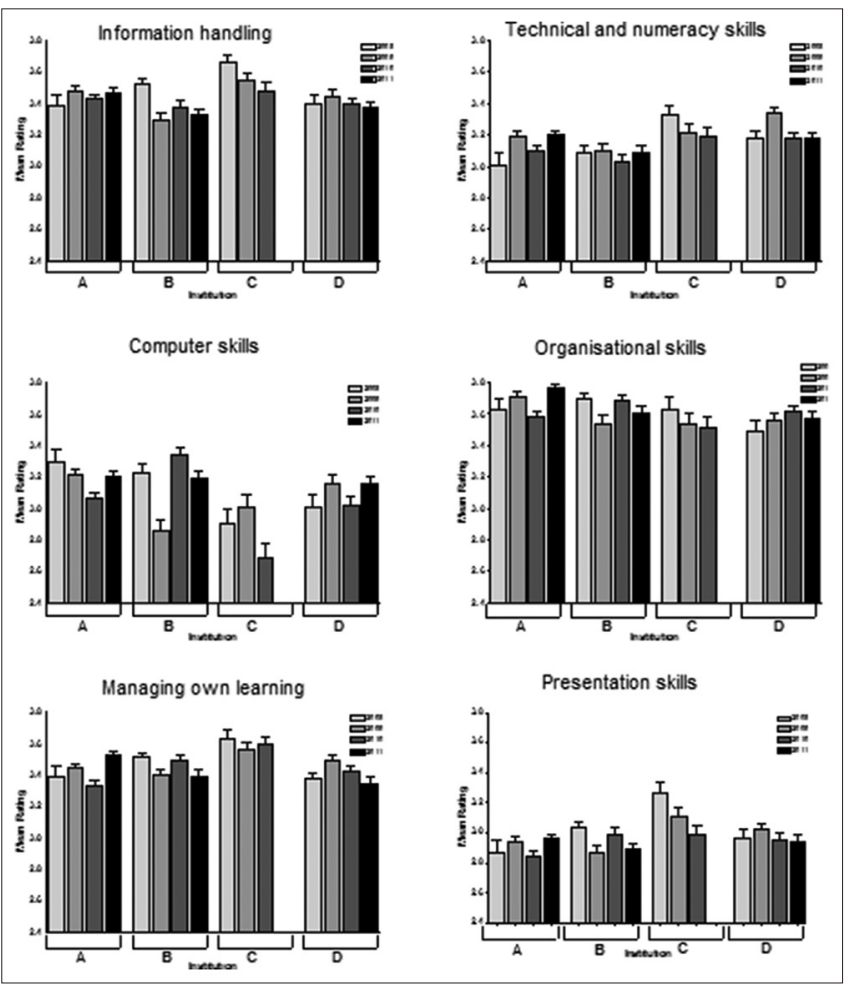

Figure 1: Mean ratings of reported frequency of practice of skills by category for entrants at the four medical schools during 2008-2011. The number of respondents for each school for the 4 years studied is as follows: A (231, 205, 231, and 263); B (151, 144, 144, and 147); C $(74,108,93)$; D $(105,168,214$, and 178) school, during 2008-2011. The table also shows the results of the multiple comparisons of the mean frequencies of practice for the six categories of generic learning skills evaluated for the different pairs of medical schools.

The data in Table 3 show that for each of the six categories of generic learning skills studied, there were significant differences in the mean frequency of practice of the skill for some pairs of medical schools, but not for other pairs. Institution $C$ showed significantly different mean ratings for frequency of practice of six, five, and four generic learning skill categories as compared to institutions A, B, and D, respectively. Institution A showed significantly different mean ratings for frequency of practice of three generic learning skill categories as compared to institution D. Institution B showed significantly different mean frequency of practice ratings for only one generic learning skill category as compared to institution $\mathrm{D}$; no differences were observed when compared to institution A.

\section{Generic learning skill confidence}

The mean ratings of the level of confidence for the different generic learning skill categories reported by the $1^{\text {st }}$-year medical students at the four medical schools, during 2008-2011, are presented in Figure 2.

Table 4 presents the mean levels of confidence for the six categories of generic learning skills studied in each medical school, during 2008-2011. The table also shows the results of multiple comparisons of mean levels of confidence for the six categories of generic learning skills evaluated for the different pairs of medical schools.

The data in Table 4 show that for each of the six categories of generic learning skills studied, there were significant differences in mean levels of confidence for some pairs of medical schools, but not for other pairs. Institution $C$ showed significantly lower mean levels of confidence for all six generic learning skill categories when compared to institutions A, B, and D. Institution A showed significantly different mean ratings of confidence for one generic learning skill category when compared to institutions B or D. Institution B showed no significant differences in levels of confidence for each of the six categories of generic learning skills when compared to institution D.

\section{Discussion}

This study shows that major pre-university education curricular changes in South Africa have not had a systematic and beneficial impact on the practice of, and confidence in, generic learning skills of South African medical school entrants. There were, however, some significant inter-institutional differences in specific aspects of the generic learning skill profiles of students at the time of entering the respective medical schools. These two findings are most likely due to the long-standing 
Burch, et al:: Pre-university curriculum reform and generic learning skills

\begin{tabular}{|c|c|c|c|c|c|c|c|c|c|c|}
\hline \multirow{2}{*}{$\begin{array}{l}\text { Generic learning } \\
\text { skill category }\end{array}$} & \multicolumn{4}{|c|}{ Mean learning skill rating for $2008-2011(95 \% \mathrm{Cl})$} & \multicolumn{6}{|c|}{ Bonferroni's multiple comparison test } \\
\hline & $A(n=930)$ & $B(n=586)$ & $C(n=275)$ & $D(n=665)$ & $A$ versus $B$ & A versus C & A versus $D$ & B versus C & B versus $D$ & C versus $D$ \\
\hline $\begin{array}{l}\text { Information } \\
\text { handling skills }\end{array}$ & $3.44(3.41-3.47)$ & $3.38(3.34-3.42)$ & $3.55(3.493 .61)$ & $3.40(3.36-3.44)$ & NS & $P<0.01$ & NS & $P<0.001$ & NS & $P<0.001$ \\
\hline $\begin{array}{l}\text { Technical and } \\
\text { numeracy skills }\end{array}$ & $3.13(3.103 .16)$ & $3.08(3.03-3.12)$ & $3.24(3.17-3.31)$ & $3.22(3.183 .25)$ & NS & $P<0.01$ & $P<0.01$ & $P<0.001$ & $P<0.001$ & NS \\
\hline Computer skills & $3.19(3.15-3.23)$ & $3.15(3.10-3.21)$ & $2.87(2.76-2.98)$ & $3.09(3.043 .15)$ & NS & $P<0.001$ & $P<0.05$ & $P<0.001$ & NS & $P<0.001$ \\
\hline $\begin{array}{l}\text { Organizational } \\
\text { skills }\end{array}$ & $3.68(3.64-3.71)$ & $3.63(3.59-3.67)$ & $3.56(3.48-3.63)$ & $3.57(3.53-3.62)$ & NS & $P<0.01$ & $P<0.01$ & NS & NS & NS \\
\hline $\begin{array}{l}\text { Managing own } \\
\text { learning skills }\end{array}$ & $3.43(3.403 .46)$ & $3.45(3.41-3.48)$ & $3.59(3.54-3.65)$ & $3.41(3.38-3.45)$ & NS & $P<0.001$ & NS & $P<0.001$ & NS & $P<0.001$ \\
\hline $\begin{array}{l}\text { Presentation } \\
\text { skills }\end{array}$ & $2.91(2.872 .94)$ & $2.95(2.90-2.99)$ & $3.11(3.04-3.18)$ & $2.97(2.93-3.01)$ & NS & $P<0.001$ & NS & $P<0.001$ & NS & $P<0.01$ \\
\hline
\end{tabular}

NS=Statistically nonsignificant (i.e., $P>0.05), \mathrm{Cl}$ : Confidence interval

Table 4: Comparison: Entrants' mean generic learning skill confidence ratings at four South Airican medical schools (20082011)

\begin{tabular}{|c|c|c|c|c|c|c|c|c|c|c|}
\hline \multirow{2}{*}{$\begin{array}{l}\text { Generic learning } \\
\text { skill category }\end{array}$} & \multicolumn{4}{|c|}{ Mean learning skill rating for $2008-2011(95 \% \mathrm{Cl})$} & \multicolumn{6}{|c|}{ Bonferroni's multiple comparison test } \\
\hline & $A(n=930)$ & $\mathrm{B}(n=586)$ & $C(n=275)$ & $\mathrm{D}(n=665)$ & $A$ versus $B$ & $A$ versus $C$ & $A$ versus $D$ & B versus $C$ & B versus $D$ & C versus $D$ \\
\hline $\begin{array}{l}\text { Information } \\
\text { handling skills }\end{array}$ & $3.09(3.06-3.12)$ & $3.13(3.09-3.17)$ & $2.75(2.68-2.82)$ & $3.06(3.01-3.10)$ & NS & $P<0.001$ & NS & $P<0.001$ & NS & $P<0.001$ \\
\hline $\begin{array}{l}\text { Technical and } \\
\text { numeracy skills }\end{array}$ & $2.96(2.92-2.99)$ & $3.02(2.97-3.06)$ & $2.62(2.55-2.69)$ & $2.98(2.94-3.02)$ & NS & $P<0.001$ & NS & $P<0.001$ & NS & $P<0.001$ \\
\hline Computer skills & $2.99(2.95-3.04)$ & $3.13(3.07-3.19)$ & $2.60(2.49-2.71)$ & $3.05(3.00-3.11)$ & $P<0.01$ & $P<0.001$ & NS & $P<0.001$ & NS & $P<0.001$ \\
\hline Organizational skills & $3.24(3.20-3.28)$ & $3.19(3.14-3.24)$ & $2.90(2.82-2.97)$ & $3.13(3.08-3.18)$ & NS & $P<0.001$ & $P<0.01$ & $P<0.001$ & NS & $P<0.001$ \\
\hline $\begin{array}{l}\text { Managing own } \\
\text { learning skills }\end{array}$ & $3.15(3.12-3.18)$ & $3.15(3.11-3.19)$ & $2.94(2.87-3.01)$ & $3.11(3.07-3.15)$ & NS & $P<0.001$ & NS & $P<0.001$ & NS & $P<0.001$ \\
\hline Presentation skills & $2.85(2.82-2.89)$ & $2.93(2.88-2.97)$ & $2.73(2.65-2.81)$ & $2.91(2.87-2.96)$ & NS & $P<0.05$ & NS & $P<0.001$ & NS & $P<0.001$ \\
\hline
\end{tabular}

NS: Statistically nonsignificant (i.e., P>0.05). Cl: Confidence interval

inequitable distribution of pre-university education resources and significant differences in the socioeconomic status (SES) of the environment/community, including the SES of the schools, in various regions of the country. ${ }^{[19]}$ While both these factors are largely linked to race in South Africa, the effect of differences in SES on academic performance in pre-university education has also been demonstrated in settings where SES is not linked to race and ethnicity. ${ }^{[26]}$

The findings of our study differ quite considerably from those described following high school curriculum changes in the UK (Curriculum 2000). Whittle and Murdoch-Eaton observed that frequency of practice of information technology skills improved, while frequency of practice of technical and numeracy skills declined; the latter was accompanied by a similar reduction in levels of confidence. ${ }^{[12]}$ In this study, the authors suggested that the increased knowledge requirements of the broader curriculum (increased number and scope of courses studied) may be "squeezing out" opportunities to practise and develop key generic learning skills. The contrast between these findings and our data highlights the context-dependent nature of generic learning skill profiles and speaks to the limited generalizability of such research findings. The need to explore these issues in each unique setting, in order to tailor academic offerings to respond to specific curriculum demands and diverse student backgrounds and educational experiences, ${ }^{[27]}$ is clear.

The third important finding of this study is the observation that students from low SES communities and poorly resourced educational backgrounds entering a rural medical school (university C) had consistently lower mean levels of reported confidence for each generic learning skill category as compared to students from better resourced backgrounds. This lack of confidence was reported despite significantly more frequent opportunities to practise four of the six categories of skills studied, namely, information handling skills, technical and numeracy skills, managing self-learning, and presentation skills. These students only reported less frequent opportunities to practise computer skills and organizational skills. This lack of confidence may relate to self-determination theory and the impact of socioenvironmental factors, such as poverty, that hinder or undermine self-motivation, social functioning, and personal well-being. Further work is needed to explore this observation and to identify strategies for improving the confidence of students from disadvantaged settings by addressing these three basic psychological needs. ${ }^{[28]}$

This study has two potential limitations. First, the study included only four of the eight medical schools in South Africa. 


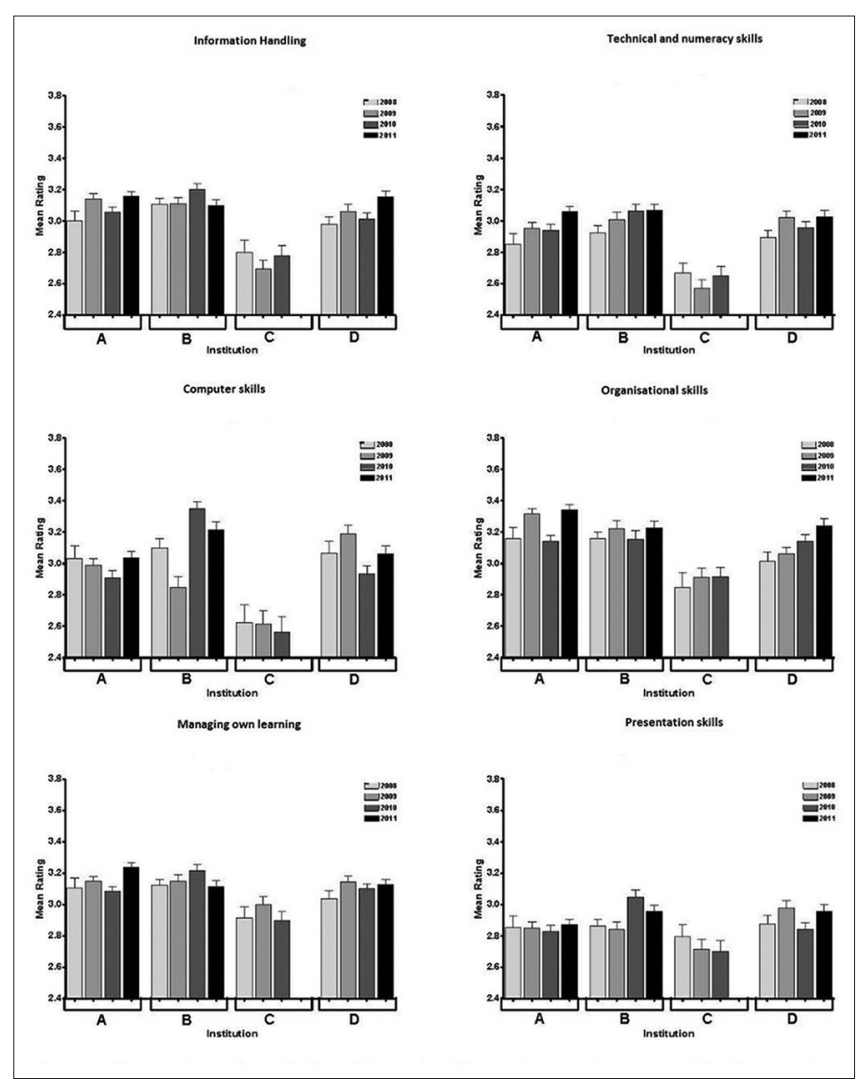

Figure 2: Mean ratings of reported confidence in skills by category for entrants at the four medical schools during 2008-2011. The number of respondents for each school for the 4 years studied is as follows: $A$ (231, 205, 231, and 263); B (151, 144, 144, and 147); C (74, 108, 93); $\mathrm{D}(105,168,214$, and 178)

However, as discussed, these four medical schools represent the full spectrum of diversity of South African medical school entrants with respect to ethnicity, geographic location, SES, and educational background. Furthermore, the differences in generic skill profiles observed in the four medical schools included in this study are consistent with a recent report investigating the generic skill profiles of entrants to all the eight South African medical schools. ${ }^{[25]}$ Second, this study only looked at changes over a 4-year period (2008-2011). While this may limit the long-term validity of our data, the first 4 years after a major pre-university curriculum revision process is likely to best reflect the direct impact of curriculum change before other extraneous factors start modulating the impact of such changes.

Hence, what are the lessons learned from this study? First, the impact of pre-university education curriculum reform on the generic learning skill profiles of university entrants is not predictable and needs to be verified to ensure that academic programs are aligned with the actual generic learning skill profiles of students. Second, university entrants from diverse educational backgrounds have variable generic learning skill profiles. Careful review within each educational setting is unique and requires tailoring of programs so that they address the specific needs of all university entrants. Third, the impact of pre-university education curricular changes is likely to be limited if implemented in settings of pre-existing inequitable distribution of basic education resources. The mandate to address these issues in parallel is clear.

\section{Conclusions}

Our work highlights the need for universities to remain informed about, and monitor, the impact of pre-university education, including curriculum reform initiatives, on the generic learning skills of prospective students. This will ensure that medical schools, particularly those engaged in widening participation, continue to provide appropriate and timely interventions for entrants from diverse educational backgrounds. ${ }^{[29-34]}$ Ongoing research in this area of higher education will contribute to sustaining the success of these initiatives.

\section{Acknowledgments}

We are grateful to the following colleagues from participating universities: Professor Ben van Heerden, Professor Juanita Bezuidenhout, Dr. Alwyn Louw (University of Stellenbosch), Dr. Brenda de Klerk (University of Free State), Professor Di Manning (University of Pretoria, previously University of the Witwatersrand), and the late Professor Enoch Kwizera (Walter Sisulu University). We are grateful to Dr. Godfrey Pell for statistical analysis and advice and to Vanessa Gray (University of Leeds, UK) for superb and unfailing patience in administration assistance and data processing.

\section{Financial support and sponsorship}

Nil.

\section{Conflicts of interest}

There are no conflicts of interest.

\section{References}

1. Barrie SC. Understanding what we mean by the generic attributes of graduates. High Educ 2006;51:215-41.

2. Zimmerman BJ, Bandura A, Martinez-Pons M. Self-motivation for academic attainment: The role of self-efficacy beliefs and personal goal setting. Am Educ Res J 1992;29:663-76.

3. Zimmerman BJ. Self-efficacy: An essential motive to learn. Contemp Educ Psychol 2000;25:82-91.

4. Paul G, Hinman G, Dottl S, Passon J. Academic development: A survey of academic difficulties experienced by medical students and support services provided. Teach Learn Med 2009;21:254-60.

5. Goldfinch J, Hughes M. Skills, learning styles and success of first-year undergraduates. Active Learn High Educ 2007;8:259-73.

6. Zimmerman BJ. Self-regulated learning and academic achievement: An overview. Educ Psychol 1990;25:3-17.

7. Sandars J, Cleary TJ. Self-regulation theory: Applications to medical education: AMEE guide no 58. Med Teach 2011;33:875-86.

8. Frenk J, Chen L, Bhutta ZA, Cohen J, Crisp N, Evans T, et al. 
Health professionals for a new century: Transforming education to strengthen health systems in an interdependent world. Lancet 2010;376:1923-58.

9. Murdoch-Eaton D, Whittle S. Generic skills in medical education: Developing the tools for successful lifelong learning. Med Educ 2012;46:120-8.

10. Whittle SR, Pell G, Murdoch-Eaton DG. Recent changes to students' perceptions of their key skills on entry to higher education. J Further High Educ 2010;34:557-70.

11. Hodgson A, Spours K. Key skills for all? The key skills qualification and Curriculum 2000. J Educ Policy 2002;17:29-47.

12. Whittle SR, Murdoch-Eaton D. Curriculum 2000: Have changes in sixth form curricula affected students' key skills? J Further High Educ 2005;29:61-71.

13. McLean M, Shaban S, Murdoch-Eaton D. Transferable skills of incoming medical students and their development over the first academic year: The United Arab Emirates experience. Med Teach 2011;33:e297-305.

14. Ministerial Project Committee Republic of South Africa. National Curriculum Statement Grades 10-12 (General) Overview. Pretoria: Department of Education; 2003. Available from: http://www.wced. school.za/ncs/lg.html\#../documents/education-related/ncs_10-12_ overview.pdf*info_ncs.html. [Last accessed on 2017 Jan 05].

15. Ministerial Project Committee Republic of South Africa. Revised National Curriculum Statement Grades R-9 Schools. Pretoria: Department of Education; 2003. Available from: http://www. education.gov.za/LinkClick.aspx?fileticket $=$ WJoXaOgvys4\%3D $\&$ tabid $=266 \& \mathrm{mid}=720$. [Last accessed on 2017 Jan 05].

16. Taylor N, Mabogoane T, Akoobhia B. Service Delivery Research Project office of the Presidency: The School Sector. Johannesburg: JET Education Services; 2011. Available from: http://www.jet.org. $\mathrm{za} /$ publications/research. [Last accessed on 2017 Jan 05].

17. Crouch L, Vinjevold P. South Africa: Access before Quality, and where to Now? In: Profesorado Rev Curr Formación Profesoradom 2006;10:1. Available from: https://www.ugr. es/ recfpro/rev101ART6ing.pdf. [Last accessed on 2017 Jan 05].

18. Taylor N, Moyana J. Khanyisa Education Support Programme: Baseline Study Part I. Johannesburg: JET Education Services; 2005. Available from: http://www.jet.org.za/publications/research. [Last accessed on 2017 Jan 05].

19. Taylor N. What's wrong with South African Schools? Johannesburg: JET Education Services; 2008. Available from: http://www.jet. org.za/publications/jet-education-services-conferences/copy_ of_What $\% 20$ works $\% 20$ in $\% 20$ school\%20development/Papers/ Taylor $\% 20$ Whats $\% 20$ wrong $\% 20$ with $\% 20$ SA $\% 20$ schools $\% 20$ JET\%20Schools\%20Conf\%20final.pdf. [Last accessed on 2017 Jan 05].

20. Van der Berg S, Louw M. Lessons learnt from SACMEQII: South African student performance in regional context. Paper Presented at the Conference on Investment Choices for Education in Africa.
Johannesburg; 19-21 September, 2006. https://ideas.repec.org/p/ sza/wpaper/wpapers47.html Accessed 5 January 2017.

21. Hoadley U, Ward C. Managing to Learn: Instructional Leadership in South African Secondary Schools. Pretoria: Human Sciences Research Council Press; 2009.

22. Fleisch B, Taylor N, Herholdt R, Sapire I. Evaluation of back to basics mathematics workbooks: A randomised control trial of the primary mathematics research project. South Afr J Educ 2011;38:488-504.

23. Brynard PA, Netshikhophani AF. Educator training challenges in implementing the National Curriculum Statement Policy. Afr J Public Aff 2011;4:60-72.

24. Dada F, Dipholo T, Hoadley U, Khembo E, Muller S, Volmink J. Report of the Task Team for the Review of the Implementation of the National Curriculum Statement. Pretoria: Department of Education; 2009

25. Murdoch-Eaton D, Manning D, Kwizera E, Burch V, Pell G, Whittle $\mathrm{S}$, et al. Profiling undergraduates' generic learning skills on entry to medical school; an international study. Med Teach 2012;34:1033-46.

26. Perry L, McConney A. Does the SES of the school matter? An examination of the socioeconomic status and student achievement using PISA 2003. Teach Coll Rec 2010;112:1137-62.

27. Lieberman SA, Ainsworth MA, Asimakis GK, Thomas L, Cain LD, Mancuso MG, et al. Effects of comprehensive educational reforms on academic success in a diverse student body. Med Educ 2010;44:1232-40.

28. Ryan RM, Deci EL. Self-determination theory and the facilitation of intrinsic motivation, social development, and well-being. Am Psychol 2000;55:68-78.

29. Garlick PB, Brown G. Widening participation in medicine. BMJ 2008;336:1111-3.

30. Alexander R, Badenhorst E, Gibbs T. Intervention programme: A supported learning programme for educationally disadvantaged students. Med Teach 2005;27:66-70.

31. Burch VC, Sikakana CN, Yeld N, Seggie JL, Schmidt HG. Performance of academically at-risk medical students in a problem-based learning programme: A preliminary report. Adv Health Sci Educ Theory Pract 2007;12:345-58.

32. Scott I, Yeld N, Hendry J. A case for improving teaching and learning in South African higher education. Higher Education Monitor. Pretoria: Council on Higher Education; 2007. p. 23-58.

33. Sikakana CNT. Supporting student-doctors from under-resourced educational backgrounds: An academic development programme. Med Educ 2010;44:917-25.

34. Burch VC, Sikakana CN, Gunston GD, Shamley DR, Murdoch-Eaton D. Generic learning skills in academically-at-risk medical students: A development programme bridges the gap. Med Teach 2013;35:671-7. 